\title{
POPULATION STATUS, HABITAT SELECTION AND \\ PEOPLE'S PERCEPTION ON PAVO CRISTATUS (AVES: PHASIANIDAE) IN SIGUR PLATEAU, THE NILGIRIS, TAMIL NADU, INDIA
}

\author{
Arockianathan Samson*, Balasundaram Ramakrishnan \\ Government Arts College, India \\ *e-mail: kingvulture1786@gmail.com
}

Received: 12.11.2017

\begin{abstract}
The present study aimed to estimate the population status, habitat utilisation and threats to the Indian peafowl in Sigur Plateau, Tamil Nadu from November 2016 to March 2017. A total of 1091 individuals of peafowls were recorded in 487 sightings in $1080 \mathrm{~km}(2.28 \pm 0.05)$ with the encounter rate of 1.01 individuals $/ \mathrm{km}$. In Dry Deciduous Forest a total of 570 individuals of peafowls were recorded in 224 sightings in $460 \mathrm{~km}(2.28 \pm 0.05$, $\mathrm{ER}=1.01$ individuals $/ \mathrm{km}$ ). In Dry Thorn Forest a total of 521 individuals of peafowls were recorded in 254 sightings in $620 \mathrm{~km}(2.05 \pm 0.06) \mathrm{ER}=0.84$ individuals $/ \mathrm{km}$. A total of 19 roosting trees species were identified, all recorded in thorn forest; similarly nine species were recorded in dry deciduous forest. The highest number of roosts were recorded in Tectona grandis $(\mathrm{n}=27)$; the average height of the tree species was $14.46 \mathrm{~m}$ and the average Indian peafowl roost height was 11.25. The Indian peafowl has decreased; the reason for invading the human habitation was the loss of food $(\mathrm{n}=60)$. Crop damage by peafowl shows that beans $(50 \%)$ were highly damaged followed by chilly (37\%), tomato $(5 \%)$ and ragi $(4 \%)$ and corn $(1 \%)$. Drivers $(n=25)$ noted that under some circumstances Pavo cristatus could be killed due to its sudden appearance on the roads.
\end{abstract}

Key words: habitat, India, Indian Peafowl, Nilgiris, population, Sigur Plateau, Tamil Nadu

\section{Introduction}

The Indian Peafowl (Pavo cristatus Linnaeus, 1758), also known as the Blue Peafowl, was declared as the national bird of India during 1963 due to its «flagship» value found on its glorious position in mythology and its widespread distribution and grandeur and comes in Schedule-I of the Indian Wildlife (Protection) Act, 1972. This bird is listed as of (LC) by the International Union for Conservation of Nature (Birdlife International, 2016). The pheasants are the group of birds belonging to the family Phasianidae of the Order Galliformes that includes pheasants, partridges and quails, commonly known as «game birds» (Delacour, 1977). McGowan \& Garson (1995) considered the pheasants as forest biodiversity indicators. Birds are widely recognised as good bioindicators of the quality of the ecosystems and a healthy environment (Gill, 1994). The Indian Peafowl is omnivorous and eats seeds, insects, fruits, small mammals, and reptiles (Panda et al., 2016). Around cultivated areas, the peafowl feeds on a wide range of crops such as groundnut (Arachis hypogaea L.), tomato (Solanum melongena L.), paddy (Oryza spp.), Red chilly (Capsicum annuum $\mathrm{L}_{\text {..) }}$ and even bananas (Musa sp.) (Johnsingh \& Murali, 1978). Indian Peafowls are polygamous and generally has to three breeding peahens in its harem (Roberts, 1991). The Indian peafowl inhabits scrub forest occupying mostly edges of the forests (John- sgard, 1986). They can be found in dry deciduous, moist deciduous, semi-arid regions, near agricultural fields and near water sources. Generally, they prefer a habitat that contains mixed patches of scrub forest and open plains. The population of the Indian peafowl is on the decline and the bird has become locally extinct in some areas of its past distribution range (Ramesh \& McGowan, 2009; Divya \& Sarita, 2013). There are numerous threats to its existing populations including habitat loss and degradation, human population pressure, illegal poaching, intensive agricultural practice and use of pesticides, retaliatory killing, the collection of eggs for consumption and killing for medicinal purposes (Anwar et al., 2015). In Pakistan, the peafowl has been extirpated from many parts of its former range due to trapping and illegal poaching of this beautiful bird (Anwar et al., 2015). Even though there is a healthy population of peafowl in different parts of the country, very few studies has been done on their population, ecology and the threats they face especially in Nilgiris, Tamil Nadu. So the status of the peafowl population of this area is poorly known. The present study aimed to estimate the population status, habitat utilisation and threats to the Indian peafowl in Sigur Plateau, Tamil Nadu from November 2016 to March 2017. The results of this study would provide base line information for developing management and conservation strategies for the Indian Peafowl. 


\section{Material and Methods}

\section{Study area}

The Sigur Plateau is at the centre of the Nilgiri Hills and is a crucial area of wildlife habitat. It is an important link between Western Ghats and Eastern Ghats. It covers an area of $778.8 \mathrm{~km}^{2}$. It comprises Nilgiris North Forest Division and $\mathrm{Mu}-$ dumalai Tiger Reserve (Fig. 1). The average elevation of the Sigur plateau is $280 \mathrm{~m}$. The boundaries of the Sigur plateau are Bandipur National Park to the northwest, Mudumalai Tiger Reserve to the west, and Sathyamangalam Tiger Reserve and Nilgiris East slope range to the east. The Sigur plateau is an excellent habitat for supporting several endangered species, e.g., the Bengal Tiger (Panthera tigris tigris (Linnaeus, 1758)), Asian elephant (Elephas maximus Linnaeus, 1758), Leopard (Panthera pardus (Linnaeus, 1758)), Wild dog (Cuon alpinus (Pallas, 1811)) Indian Gaur (Bos gaurus C.H. Smith, 1827) Black buck (Antilope cervicapra (Linnaeus, 1758)) Sloth Bear (Melursus ursinus (Shaw, 1791)), Striped hyaena (Hyaena hyaena (Linnaeus, 1758)), Marsh Crocodile (Crocodylus palustris Lesson, 1831), and Four-horned Antelope (Tetracerus quadricornis (de Blainville, 1816)). The Critically Endangered Gyps vultures such as Long-billed (Gyps indicus (Scopoli, 1786)) White-rumped (Gyps bengalensis (Gmelin, 1788)) with Egyptian (Neophron percnopterus (Linnaeus,
1758)) and Red-headed vultures (Sarcogyps calvus (Scopoli, 1786)) occur in this plateau (Ramakrishnan et al. 2012, 2014; Samson et al., 2014, 2016). The corridor between the Western Ghats and the Eastern Ghats is effectively used by the elephant, tiger, gaur and other wild animals for seasonal migration largely influenced by the southwest and northeast monsoon. The rivers such as the River Avaralla, River Jagulikadavu, and River Siriyur are the tributaries of the River Moyar which crisscrosses the Moyar valley and drain into the Bhavanisagar reservoir.

\section{Population estimation}

Line transects were laid in different habitat types and using a motor vehicle was used in the early morning (06.00 to 10.00) and late evening (03.00 to 07.00$)$ to study the abundance and density of the Peafowl in the study area. A total of 54 $\mathrm{km}$ of transects were laid in Dry Deciduous Forest $(23 \mathrm{~km})$ and Dry Thorn Forest $(31 \mathrm{~km})$ habitat type as per stratified sampling techniques in proportion to the availability of each habitat type in the study area. The transect was covered four times in each month. On each sighting of the Peafowl variables such as the total number of individuals (Adult Male, Adult Female, Sub Adult Male, Sub Adult Female and Chicks), group size, vegetation and terrain type was recorded.

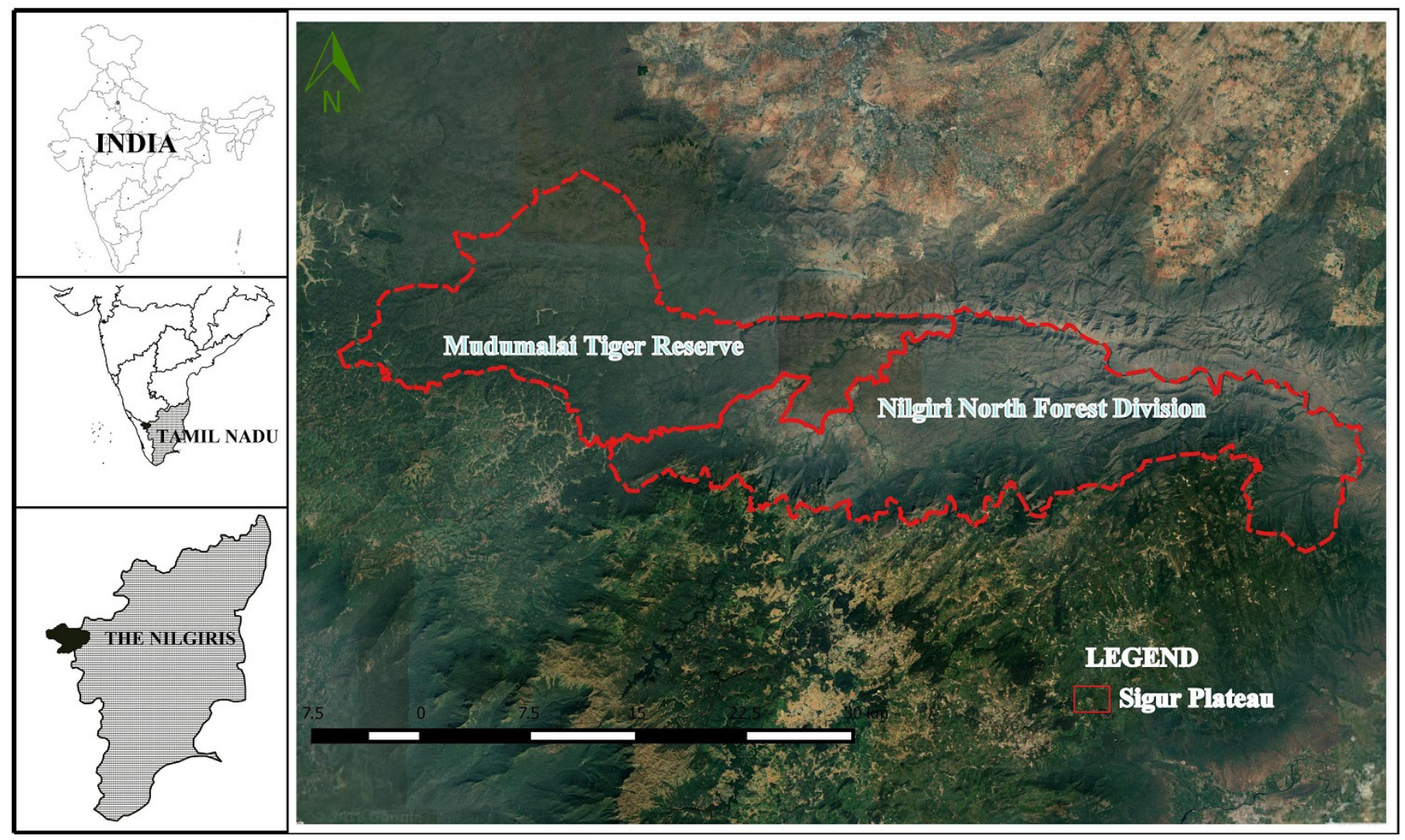

Fig. 1. The map showing the study area Sigur Plateau, the Nilgiris, Tamil Nadu, Southern India. 


\section{Sex identification}

The peacock is a classic example of birds with sexual dimorphism. The males and females have distinct features that make them look entirely different. In peacocks, the long and beautiful tail of the male is the most prominent feature that makes it look different from the female. When compared to females, males are much taller and longer. An adult male can be as long as $228.6 \mathrm{~cm}$ whereas an adult female is around 76.2 to $91.44 \mathrm{~cm}$ in length. Males have long and colourful tails with iridescent feathers. On the other hand, female peacocks or peahens possess short tails with dull brownishgray feathers. Though both males and females have white markings on the upper and lower sides of their eyes, this feature is more prominent in males. The male peacock has short and curly feathers on its head, and its fan like crest consists of small blue feathers with long bare shafts. In a peahen, the crest has brownish feathers. The male peacock has blue neck feathers that look like fur, whereas the female has dense metallic green feathers that look like scales. Females have a tendency to fluff their neck feathers in between. The back of a male peacock has scale-like feathers, which are followed by covert feathers. The female has scale-like feathers on the neck, but the feathers on their back are mostly found in shades of brown and they share a similar shape. In male peacocks, the wings can either be barred or solid in colour, whereas peahens usually have solid brown wings. Male peacocks have slightly longer legs, when compared to females. Though both sexes have spurs (thorns) on their legs, they develop earlier in males. These spurs are much shorter and blunt in females. Peacocks use their leg spurs during territorial fights.

\section{Roosting tree preference}

The Indian peafowl P. cristatus's roosting sites and trees were searched and recorded. The roost tree was confirmed seeing the birds directly at dawn and dusk. The peafowl roosting was confirmed by seeing the bird with a powerful Binocular (10X50 OLYMPUS, Olympus Europa SE \& Co. KG, Hamburg). Details such as roost tree $(n)$, roost tree height $(\mathrm{m})$, roost height $(\mathrm{m})$, tree diameter at breast height $(\mathrm{cm})$, habitat, date, time were recorded. The presence of dropping in the roost tree also evidenced the birds choosing the same tree for long period. The roost tree species were identified and recorded by following (Matthew, 1982).

\section{People Perception}

The study was targeted on farmers $(n=40)$, local people $(\mathrm{n}=33)$ and drivers $(\mathrm{n}=30)$. Two sets of questionnaire were developed for this study. One was «Precise and Closed» and the other one was «Broad and Open ended». Face to face interviews made it easier to clear any ambiguity about the questions. Information was collected through "Broad and Open ended" questions giving the respondent an opportunity to express his views freely without any inhibition (Ramakrishnan \& Saravanamuthu, 2012).

\section{Statistical Treatment}

Mean (M) and Standard Error (SE) were calculated to the Sightings of Individuals and Encounter Rate was performed to number of individuals recorded per $\mathrm{km}$ in the study area. Statistical analyses were performed by using Graph Pad Prism 5 statistical computer software.

\section{Results}

A total of 1091 individuals of peafowls were recorded in 487 sightings in $1080 \mathrm{~km}$ $(2.28 \pm 0.05)$ with the encounter rate of 1.01 individuals / km in Sigur Plateau, The Nilgiris. Of which adult females were accounted more numbers $(\mathrm{n}=228(1.68 \pm 0.04), \mathrm{ER}=0.35$ individuals $/ \mathrm{km})$ followed by sub adult female $(\mathrm{n}=313$ $(1.71 \pm 0.05), \mathrm{ER}=0.28$ individuals $/ \mathrm{km})$, adult male $(\mathrm{n}=228(1.23 \pm 0.03), \mathrm{ER}=0.21$ individuals $/ \mathrm{km}$ and juveniles $(\mathrm{n}=4(2 \pm 0) \mathrm{ER}=0.01 \mathrm{in}$ dividuals $/ \mathrm{km}$ ) (Table 1 ). The sex ratio shows that overall males and female was $0.55: 1.83$ of which adult male female sex ratio were 0.59:1.69 and sub adult males and female 0.49:2.06.

In Dry Deciduous Forest a total of 570 individuals of peafowls were recorded in 224 sightings in $460 \mathrm{~km}(2.28 \pm 0.05, \mathrm{ER}=1.01$ individuals $/ \mathrm{km})$. Of which Adult Females were accounted more numbers $(\mathrm{n}=212(1.82 \pm 0.05) \mathrm{ER}=0.46$ individuals $/ \mathrm{km}$ ) followed by Sub Adult female $(\mathrm{n}=313(1.71 \pm 0.05)$, ER $=0.28$ individuals $/ \mathrm{km})$, Adult male $(\mathrm{n}=138(1.26 \pm 0.04)$ $\mathrm{ER}=0.30$ individuals $/ \mathrm{km})$ and juveniles $(\mathrm{n}=14$ $(2 \pm 0), \mathrm{ER}=0.01$ individuals $/ \mathrm{km})($ Table 2$)$. The sex ratio shows that overall males and females 0.59:1.69 of which adult male and female sex ratio were $0.65: 1.54$ and sub adult males and females 0.51:1.97.

In Dry Thorn Forest a total of 521 individuals of peafowls were recorded in 254 sightings in $620 \mathrm{~km}$ $(2.05 \pm 0.06) \mathrm{ER}=0.84$ individuals $/ \mathrm{km}$. Of which 
Adult Females $(\mathrm{n}=172 ; 1.53 \pm 0.05)$ and Sub adult females $(\mathrm{n}=171 ; 1.61 \pm 0.05)$ were accounted more numbers with a encounter rate of 0.28 individuals / $\mathrm{km}$ respectively, followed by Adult male $(\mathrm{n}=90(1.2 \pm 0.05) \mathrm{ER}=0.15$ individuals $/ \mathrm{km})$, Sub adult male $(\mathrm{n}=80(1.26 \pm 0.06), \mathrm{ER}=0.13$ individuals $/ \mathrm{km}$ ) and juveniles were recorded minimum numbers $(\mathrm{n}=8(2 \pm 0), \mathrm{ER}=0.01$ individuals $/ \mathrm{km}$ ) (Table 3 ). The sex ratio shows that overall males and females have 0.50:2.02. Of which adult male and female sex ratio were 0.52:2.15 and sub adult males and females 0.47:2.14.

Group size results show that dry deciduous forest accounted more numbers of individuals, maximum 9 individuals and minimum 1 individual, on the other hand, dry thorn forest receives maximum 6 individuals and minimum 1 individual.

A total of 19 roosting trees species were identified of which all 19 species were recorded in thorn forest; similarly ten species were recorded in the dry deciduous forest. The highest number of roosts were recorded in Tectona grandis $\mathrm{L}$. $\mathrm{f} .(\mathrm{n}=27)$ the average height of the tree species was $14.46 \mathrm{~m}$ and the average Indian peafowl roost height was $11.25 \mathrm{~m}$ followed by Erythroxylum monogynum Roxb. $(\mathrm{n}=16)$ average height $7.12 \mathrm{~m}$ and average roost height 4.77 $\mathrm{m}$, Cassine glauca (Rottb.) Kuntze $(\mathrm{n}=15)$ average height $17.42 \mathrm{~m}$ and average roost height 8.9 $\mathrm{m}$ and Lagerstroemia lanceolata Wall. $(\mathrm{n}=12)$ average height $17.25 \mathrm{~m}$ and average roost height $6.8 \mathrm{~m}$. The lowest preference of rooting trees species was Ficus mollis Vahl $(\mathrm{n}=3)$ average height $14.5 \mathrm{~m}$ and average roost height $7.5 \mathrm{~m}$ and Manilkara hexandra (Roxb.) Dubard $(\mathrm{n}=2)$ average height $19.33 \mathrm{~m}$ and average roost height $8.0 \mathrm{~m}$ (Table 4).

The result of the Indian peafowl status and Conservation Mindset on local people in fringe areas of Sigur Plateau show that a maximum number of people replied that the population of Indian peafowl was decreasing and they claimed the main reason for invading the human habitation was the loss of food $(n=60)$, followed by habitat alteration $(n=23)$ and finally some of the people opined the forest area encroachment $(n=20)$. The people were also of the view that the Indian peafowl did not cause any threats and damages.

Table 1. Demography and population status of Peafowl in Sigur Plateau, the Nilgiris, Tamil Nadu, India

\begin{tabular}{|c|l|c|c|c|c|}
\hline № & \multicolumn{1}{|c|}{ Demography } & Sightings & Individuals & M \pm SE & ER / km \\
\hline 1 & Adult male & 184 & 228 & $1.23 \pm 0.03$ & 0.21 \\
\hline 2 & Adult female & 228 & 384 & $1.68 \pm 0.04$ & 0.35 \\
\hline 3 & Sub-adult male & 115 & 152 & $1.32 \pm 0.05$ & 0.14 \\
\hline 4 & Sub-adult female & 182 & 313 & $1.71 \pm 0.05$ & 0.28 \\
\hline 5 & Juveniles & 7 & 14 & $2 \pm 0$ & 0.01 \\
\hline Total & & 487 & 1091 & $2.28 \pm 0.05$ & 1.01 \\
\hline
\end{tabular}

Table 2. Demography and population status of Indian peafowl in Dry Deciduous Forest, the Nilgiris, Tamil Nadu, India

\begin{tabular}{|c|l|c|c|c|c|}
\hline № & \multicolumn{1}{|c|}{ Demography } & Sightings & Individuals & $\mathbf{M} \pm \mathbf{S E}$ & $\mathbf{E R} / \mathbf{k m}$ \\
\hline 1 & Adult male & 109 & 138 & $1.26 \pm 0.04$ & 0.30 \\
\hline 2 & Adult female & 116 & 212 & $1.82 \pm 0.05$ & 0.46 \\
\hline 3 & Sub-adult male & 52 & 72 & $1.38 \pm 0.07$ & 0.16 \\
\hline 4 & Sub-adult female & 76 & 142 & $1.86 \pm 0.09$ & 0.31 \\
\hline 5 & Juveniles & 3 & 6 & $2 \pm 0$ & 0.01 \\
\hline Total & 224 & 570 & $2.54 \pm 0.09$ & 1.24 \\
\hline
\end{tabular}

Table 3. Demography and population status of Indian peafowl in Thorn Forest of Sigur Plateau, the Nilgiris, Tamil Nadu, India

\begin{tabular}{|c|l|c|c|c|c|}
\hline № & \multicolumn{1}{|c|}{ Demography } & Sightings & Individuals & $\mathbf{M} \pm \mathbf{S E}$ & $\mathbf{E R} / \mathbf{k m}$ \\
\hline 1 & Adult male & 75 & 90 & $1.2 \pm 0.05$ & 0.15 \\
\hline 2 & Adult female & 112 & 172 & $1.53 \pm 0.05$ & 0.28 \\
\hline 3 & Sub-adult male & 63 & 80 & $1.26 \pm 0.06$ & 0.13 \\
\hline 4 & Sub-adult female & 106 & 171 & $1.61 \pm 0.05$ & 0.28 \\
\hline 5 & Juviniles & 8 & 8 & $2 \pm 0$ & 0.01 \\
\hline Total & & 254 & 521 & $2.05 \pm 0.06$ & 0.84 \\
\hline
\end{tabular}


Table 4. Roosting tree selection and characteristics of Indian Peafowl in Sigur Plateau, the Nilgiris, Tamil Nadu, India

\begin{tabular}{|c|c|c|c|c|c|c|}
\hline № & Tree species & No & Height (m) & DBH (cm) & Roost height (m) & Habitat \\
\hline 1 & Terminalia arjuna (Roxb. ex DC.) Wight \& Arn & 11 & 23.5 & 452.79 & 8.12 & TF/DDF \\
\hline 2 & Ficus benghalensis L. & 5 & 12.83 & 530 & 7.33 & $\mathrm{TF} / \mathrm{DDF}$ \\
\hline 3 & Ficus mollis Vahl & 2 & 14.5 & 407.5 & 7.5 & $\mathrm{TF}$ \\
\hline 4 & Lagerstroemia lanceolata Wall. & 12 & 17.25 & 230.5 & 6.8 & $\mathrm{TF}$ \\
\hline 5 & Bambusa bambos (L.) Voss & 6 & 29.5 & - & 9 & $\mathrm{TF} / \mathrm{DDF}$ \\
\hline 6 & Erythroxylum monogynum Roxb. & 16 & 7.12 & 98.5 & 4.77 & TF \\
\hline 7 & Cassia fistula L. & 5 & 12.25 & 193 & 7.14 & TF/DDF \\
\hline 8 & Azadirachta indica A.Juss. & 6 & 16.25 & 286.5 & 10.5 & TF \\
\hline 9 & Manilkara hexandra (Roxb.) Dubard & 3 & 19.33 & 256 & 8 & TF \\
\hline 10 & Tamarindus indica L. & 8 & 13.83 & 345 & 8 & $\mathrm{TF}$ \\
\hline 11 & Grevillea robusta A.Cunn. ex R.Br. & 7 & 19.25 & 201.4 & 7.28 & TF \\
\hline 12 & Ziziphus zeyheriana Sond & 8 & 5.66 & 81.66 & 4.5 & TF/DDF \\
\hline 13 & Cassine glauca (Rottb.) Kuntze & 15 & 17.42 & 325.68 & 8.9 & $\mathrm{TF}$ \\
\hline 14 & Chloroxylon swietenia DC & 9 & 7.69 & 111.5 & 6.5 & $\mathrm{TF}$ \\
\hline 15 & Pongamia pinnata (L.) Pierre & 5 & 9.25 & 102.5 & 6.54 & $\mathrm{TF} / \mathrm{DDF}$ \\
\hline 16 & Pterocarpus marsupium Roxb. & 7 & 7.28 & 115.28 & 5.44 & TF/DDF \\
\hline 17 & Syzygium cumini (L.) Skeels & 4 & 19.5 & 245 & 9.66 & TF/DDF \\
\hline 18 & Tectona grandis L.f. & 27 & 14.46 & 215.67 & 11.25 & TF/DDF \\
\hline 19 & Spondias pinnata (L. f.) Kurz & 12 & 13.27 & 310.25 & 8.12 & TF/DDF \\
\hline
\end{tabular}

Note: $\mathrm{DBH}$ - tree diameter at breast height

A total of 40 farmers were interviewed to analysis the damages caused by Indian peafowl in agricultural fields (Fig. 2). Beans were highly damaged by Indian peafowl followed by (Capsicum annuum L.) - 37\%, tomato (Solanum lycopersicum L.) 5\% and ragi (Eleusine coracana (L.) Gaertn.) - 4\%; on the other hand corn (Zea mays L.) was minimally damaged by Indian peafowl. There is no preventive measure to stop the Indian peafowl causing damage to the agricultural fields. The majority of the farmers $(n=30)$ are very angry for their loss on their agricultural field due to Indian peafowl damages, on the other hand, a considerable number of farmers $(\mathrm{n}=10)$ accepts it is a natural one. It is interesting to note that all farmers are welfare for the Indian peafowl conservation in this region. The study results of the Indian peafowl conservation mindset on drivers in Sigur Plateau show that the drivers have good knowledge about the Indian peafowl conservation and drivers $(n=25)$ replied that under some circumstances the Indian peafowl are victims of road kills due to its sudden appearance on the roads.

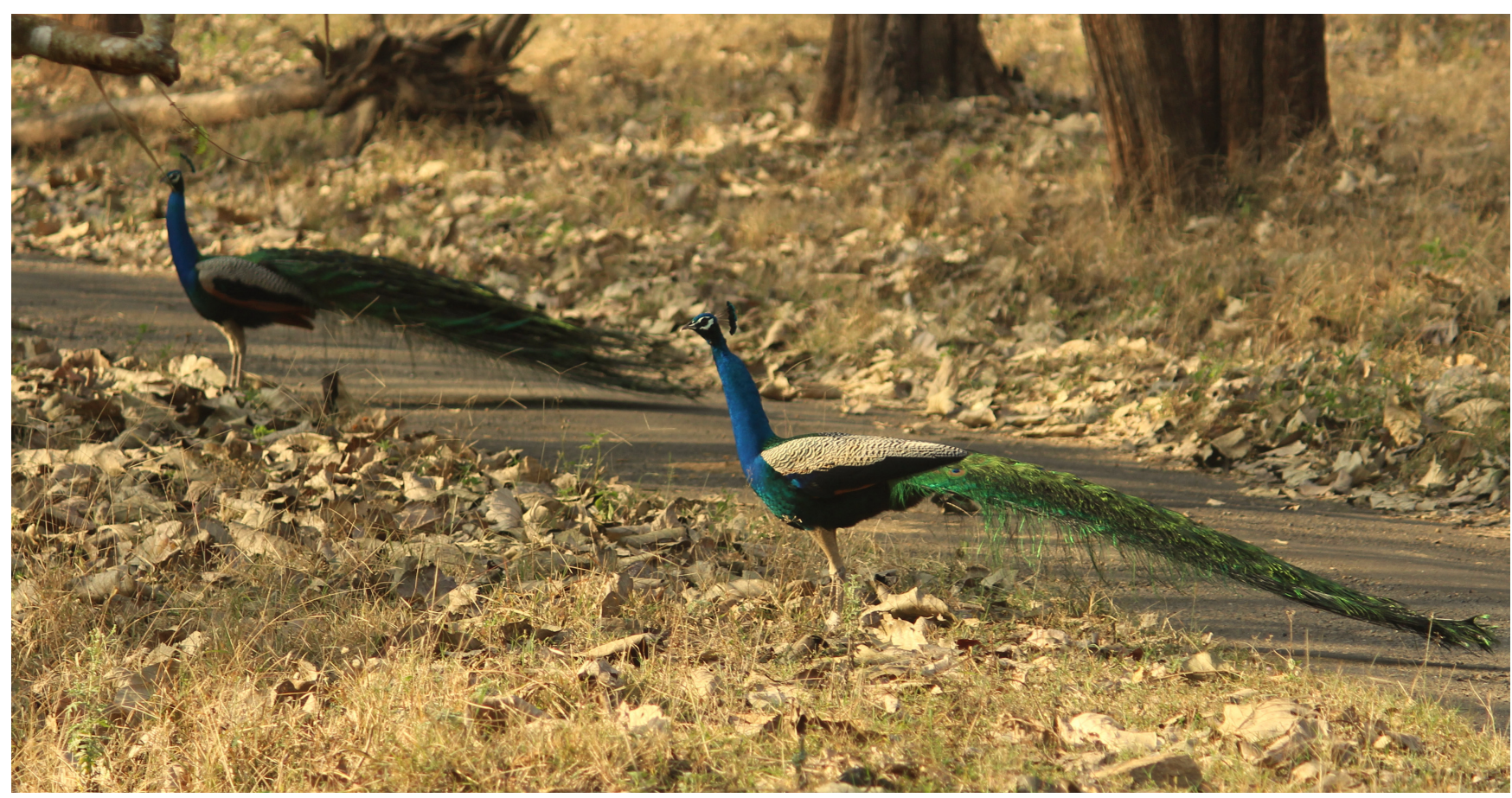

Fig. 2. Individuals of Pavo cristatus Linnaeus, 1758. 


\section{Discussion}

The present study on the survey of peafowls was carried out in two different selected habitats of Sigur Plateau. A total of 1091 peafowls consisting of 228 adult males, 384 adult females, 152 subadult male, 313 sub-adult female and 14 juveniles were counted in 487 repeated sightings in 1080 $\mathrm{km}$ of transect with the encounter rate of 1.01 . The sex ratio of adult males and females was 380:697 $(0.55: 1.83)$. Veeramani (1990) recorded that in the same region (Mudumalai Tiger Reserve) a total of 234 peafowls, consisting of 111 males, $105 \mathrm{fe}-$ males and 18 sub-adults, were counted in an area of $23.50 / \mathrm{km}^{2}$. The sex ratio of adult males and females was 111:105 (1:0.95). Similarly, Sharma (1979) reported a sex ratio of the peafowls of 170-210:100 (1:0.59) in Jodhpur, Rajasthan. On the other hand, Johnsingh \& Murali (1978) and Rajadurai (1988) reported a sex ratio of 47:100 $(1: 2.1)$ and 1468:1677 (1:1.4) Injar and Viralimalai in Tamilnadu respectively.

The maximum numbers of peafowls have been found in the dry deciduous forest: 570 individuals were recorded in 254 sightings with the encounter rate of $1.24 / \mathrm{km}$. McGowan \& Garson (1995) stated that the peafowl is a bird of scrub jungles, and Brickle (2002) noted that it shows affinity to deciduous forests and semiarid biomes; it could also be found in agricultural fields (Sathyanarayana, 2004). It prefers open areas as sites for lekking and dust bathing (Yasmin \& Yahya, 1996; Harikrishnan et al., 2010). The previous study recorded that Thorn forest (scrub jungle) with a density of 133 birds $/ \mathrm{km}^{2}$ was recorded in Mudumalai Tiger Reserve (Veeramani, 1990). The high abundance of peafowls in the dry deciduous forest may be due to the availability of sufficient food plants, insects, roosting trees and a good ground cover for breeding and protection. Trivedi \& Johnsingh (1995) reported that the scrub jungle habitat had thickets with climbers in the canopy, possessed thorny undergrowth and steep river banks with tall trees provided the peafowls to escape from the predators.

Roost selection is a vital component of the overall habitat selection process; therefore information on roost selection by a species carries immense importance for assessing its conservation needs. Judicious selection of roosting sites enhances the survival of birds by virtue of reduced heat loss, information sharing accountability of population and better protection from predators (Gadgil, 1972; Gadgil \& Ali, 1975; Dodia, 2011). In the present study, it was found that most of the time with sun, peafowl rest in the shade and in the evening time they rest in open areas. Those tree species they select for roosting may or may not coincide with the resting tree species in daytime. The peafowls prefer stout and sparse branches of trees which can withstand the birds' weight and where peafowls would also be able to move without obstacles (Sharma, 1983; Parasharya \& Mukherjee, 1999). A total of 19 tree species were recorded as roosting tree species. It is interesting to note that in the present study the maximum number of roosting peafowls was found in Tectona grandis $(16 \%)$ followed by Erythroxylum monogynum (10\%), Cassine glauca (9\%), Lagerstroemia lanceolata (7\%), and Spondias pinnata (L. f.) Kurz (7\%). The previous study reported that in Acacia catechu (L. f.) Willd. (69\%) the maximum number of roosting was recorded. (Veeramani, 1990). Sathyanarayana \& Veeramani (1993) reported Acacia catechu with $78.36 \%$ of roosting. Similarly, Navaneethakannan (1981) has also recorded that peafowls usually roost in Acacia spp. On the other hand, Rajadurai (1988) reported that the maximum number of peafowls roost in Tamarindus indica L. (35.62\%) trees in semi-wild conditions. And Trivedi \& Johnsingh (1995) reported that the peafowls preferred to roost on Pongamia pinnata (L.) Pierre and Holoptelea integrifolia Planch. in Gir forest of Gujarat, India. It was observed that the peafowls preferred to roost at different heights and branches of the tree. Most of the peafowls were found roosting at a height of 5-19 $\mathrm{m}$, an average height of $8.12 \mathrm{~m}$. Trivedi \& Johnsingh (1995) recorded that peafowls roost at heights of above $15 \mathrm{~m}$ in Gir Forest. Most of the peafowls were found roosting at a height of 16$22 \mathrm{~m}$. As reported by Veeramani (personal communication), this is to protect themselves against predators. Based on the present study it can be said that the peafowls are active between 06:40 and 10:00 a.m. and 4:00 and 6:30 p.m. Similarly, Hillgarth (1984) reported that the peafowls were most active between 09:00 and 11:00 a.m. and 5:00 and 6:00 p.m. Navaneethakannan (1984) also observed that the peafowls were most active in the early morning and afternoon. Rathinasabapathi (1987) reported that the peafowls are most active between 06:00 and 11:00 a.m. and 4:00 and 6:00 p.m. hours and they took a rest between 11:00 a.m. and 15:00 p.m. in Prosopis juliflora (Sw.) DC. scrub shade. The present study revealed that the peafowls took a rest in Lantana camara L. bushes in the afternoon . 
The Indian Peafowl is omnivorous and eats seeds, insects, fruits, small mammals, and reptiles. They feed on small snakes but keep their distance from larger ones (Johnsingh, 1976). The plant matter constituted the bulk of the diet of Indian Peafowl and the animal matter was found only in low proportions (Navaneethakannan, 1981). In the present study around the cultivated areas, the peafowl feeds on a wide range of crops such as beans, chilly, capsicum, tomato, maize. The previous study reported that paddy, bajra, other grain seeds and partial to agricultural crops and garden plants as revealed by villagers and priests (Veeramani, 1990). Johnsingh \& Murali (1978) reported that around cultivated areas, peafowl feeds on a wide range of crops such as groundnut, tomato, paddy, chilly and even bananas.

Peafowl is regarded as one of the serious pests of agriculture. The use of pesticides in agriculture also poses a threat especially to the chicks (McGowan \& Garson, 1995). Peacocks are also caught for their magnificent tail feathers. In agricultural areas and in home gardens, peafowl has also been attacked by dogs. Sigur is an area of high potential for agriculture, and as a result, there would be an increased pressure on fallow lands to be brought under the plow. Such conversions of land for agriculture would greatly reduce the habitat for peafowl and will bring the species into conflict with farmers. The key to long-term survival of the peafowl is the reduction of such conflicts and the maintenance of large tracts of scrub forest and associated grassland with an undisturbed access to water.

\section{References}

Anwar M., Mahmood A., Rais M., Hussain I., Ashraf N., Khalil S., Qureshi B.D. 2015. Population Density and Habitat Preference of Indian Peafowl (Pavo cristatus) in Deva Vatala National Park, Azad Jammu \& Kashmir, Pakistan. Pakistan Journal of Zoology 47(5): 1381-1386.

BirdLife International. 2016. Pavo cristatus. In: The IUCN Red ListofThreatened Species 2016: e.T22679435A92814454. Available from: http://dx.doi.org/10.2305/IUCN. UK.20163.RLTS.T22679435A92814454.en.

Brickle N.W.2002. Habitat use, predicted distribution and conservation of green peafowl (Pavo muticus) in Dak Lak Province, Vietnam. Biological Conservation 105: 189-197. DOI: 10.1016/S0006-3207(01)00182-3

Delacour J. 1977. The Pheasants of the World. $2^{\text {nd }}$ edition. Spur Publications. 434 p.

Dodia P.P. 2011. Roost tree selection by the common Indian peafowl (Pavo cristatus) at Bhavnagar District, Gujarat (India). Life Science Leaflet 11: 346-354.
Divya J., Sarita R. 2013. Population indices and habitat association of Indian Peafowl (Pavo cristatus) in Haryana using line transect and call count method. Indian Journal of Animal Research 47: 152-155.

Gadgil M. 1972. The function of Communal roost: relevance of mixed roosts. Ibis 114(4): 531-533.

Gadgil M., Ali S. 1975. Communal roosting habits of Indian birds. Journal of Bombay Natural History Society 72(3): 716-727.

Gill F.B. 1994. Ornithology. $2^{\text {nd }}$ edition. New York: Oxford University Press. 117 p.

Harikrishnan S., Vasudevan K., Sivakumar K. 2010. Behavior of Indian Peafowl Pavo cristatus Linn. 1758 during the mating period in a Natural Population. The Open Ornithology Journal 3: 13-19.

Hillgarth N. 1984. Social organization of the wild peafowl in India. Journal of World Pheasant Association 9: 47-56.

Johnsgard P.A. 1986. The Pheasants of the World. Oxford: Oxford University Press. 204 p.

Johnsingh A.J.T., Murali S. 1978. The ecology and behavior of the Indian peafowl (Pavo cristatus) Linn.of Injar, Tamilnadu. Journal of Bombay Natural History Society 75: 1069-1079.

Johnsingh A.J.T. 1976. Peacocks and cobra. Journal of Bombay Natural History Society 73(1): 214.

Matthew K.M. 1982. Illustrations on the Flora of the Tamilnadu Carnatic. Tiruchirapalli, India: Rapinat Herbarium, St. Joseph's College. 1027 p.

McGowan P.J.R., Garson P. 1995. Status survey and conservation action plan (1995-1999): Pheasants. Gland, Switzerland: IUCN \& World Pheasant Association. $116 \mathrm{p}$.

Navaneethakannan K. 1981. Activity patterns in a colony of peafowl (Pavo cristatus) in nature. Journal of Bombay Natural History Society 81(2): 387-393.

Panda S., Panigrahi G.K., Padhi S. 2016. Wild Animals of India. Hamburg: Anchor Academic Publishing. 67 p.

Parasharya B.M., Mukherjee A. 1999. Roosting behaviour of Indian Peafowl Pavo cristatus. Journal of Bombay Natural History Society 96(3): 471-472.

Rajadurai T. 1988. Present distribution and status of Indian peafowl (Pavo cristatus) in Viralimalai area, Tamil Nadu, and South India. M.Sc. Dissertation: A.V.C. College, Mannampandal.

Ramesh K., McGowan P. 2009. On the current status of Indian Peafowl Pavo cristatus (Aves: Galliformes: Phasianidae): keeping the common species common, Journal of Threatened Taxa 1(2): 106-108.

Ramakrishnan B., Ramasubramanian S., Samson A. 2012. Occurrence of Red-headed vulture in Sigur plateau, Tamil Nadu. Current Science 102(6): 832.

Ramakrishnan B., Saravanamuthu R. 2012. Conservation and Management of Elephant Corridors: Ecology, Human-Elephant Conflict, Capacity Building. Saarbrücken, Germany: Lap Lambert Academic Publishing. 208 p.

Ramakrishnan B., Kannan G., Samson A., Ramkumar K., Ramasubramanian S. 2014. Nesting of Whiterumped vulture (Gyps bengalensis) in the Sigur 
Plateau of The Nilgiri North Forest Division. Indian Forester 140(10): 1014-1018.

Rathinasabapathi B. 1987. Activity patterns with special reference to food and feeding habits of the Indian Peafowl, Pavo cristatus in Viralimalai area, Tamilnadu. M.Sc. Thesis. Tamil Nadu: Bharathidasan University. 27 p.

Roberts T.J. 1991. The Birds of Pakistan, Vol. 1. Nonpasseriformes. Karachi: Oxford University Press. 617 p.

Samson A., Ramakrishnan B., Renuka S., Ravi P., Ramasubramanian S. 2014. Bathing behavior and waterhole importance of white-rumped vulture conservation in the Sigur Plateau, Tamil Nadu, Southern India. Journal of Applied Science and Research 2(5): 92-99.

Samson A., Ramakrishnan B., Veeramani A., Ravi P. 2016. Population Status and Habitat Preference of Vultures in Mudumalai Tiger Reserve, Tamil Nadu, Southern India. Podoces 11(1): 7-12.

Sathyanarayana M.C. 2004. Bird pest management with special reference to Indian peafowl Pavo cristatus in Tamilnadu, India. In: R.A. Fuller, S.J. Browne (Eds): Galliformes 2004.
Proceedings of the 3rd International Galliformes Symposium. Fordingbridge, UK: World Pheasant Association.

Sathyanarayana M.C., Veeramani A. 1993. Roosting trees used by blue peafowl at Tamilnadu. In: D. Jenkins (Ed.): Pheasant in Asia. Reading, UK: World Pheasant Association. P. 144-145.

Sharma I.K. 1979. Ecological aspects of population trends of the peafowl (Pavo cristatus) at Jodhpur, India. Pavo 17(1-2): 50-53.

Sharma I.K. 1983. Roost site of birds around Jodhpur. Newsletters for Bird Watchers 13(1-2): 8-9.

Trivedi P., Johnsingh A.J.T. 1995. Diet of Indian Peafowl Pavo cristatus Linn. in Gir Forest, Gujarat. Journal of Bombay Natural History Society 92(1-3): 262-263.

Veeramani A. 1990. Studies on ecological and behavioural aspects of Indian Peafowl Pavo cristatus in Mudumalai Wildlife Sanctuary, Tamil Nadu, South India. M.Sc. Thesis. Tamil Nadu: Bharathidasan University.

Yasmin S., Yahya H.S.A. 1996. Correlation of mating success in Indian peafowl. The Auk: Ornithological Advances 113(2): 490-492.

\title{
СОСТОЯНИЕ ПОПУЛЯЦИИ, ИЗБИРАТЕЛЬНОСТЬ МЕСТООБИТАНИЙ И ВОСПРИЯТИЕ ЛЮДЬМИ РАVО CRISTATUS (AVES: PHASIANIDAE) НА ПЛАТО СИГУР, ОКРУГ НИЛГИРИ, ШТАТ ТАМИЛНАД, ИНДИЯ
}

\author{
А. Самсон ${ }^{*}$, Б. Рамакришнан \\ Правительственный колледж искусств, Индия \\ *e-mail: kingvulture1786@gmail.com
}

\begin{abstract}
Целью настоящего исследования стало оценить состояние популяции, использование мест обитания и угроз для обыкновенного павлина на плато Сигур с ноября 2016 г. до марта 2017 г. В целом в 487 наблюдениях на протяжении 1080 км (2.28 \pm 0.05$)$ было зарегистрировано 1091 особей павлина с частотой встречаемости 1.01 особей / км. В сухом лиственном лесу было зарегистрировано в общей сложности 570 особей павлинов в 224 наблюдениях на протяжении 460 км $(2.28 \pm 0.05, \mathrm{ER}=1.01$ особей / км $)$. В сухом колючем лесу была зарегистрирована в общей сложности 521 особь павлинов в 254 наблюдениях на протяжении 620 км $(2.05 \pm 0.06, \mathrm{ER}=0.84$ особей / км). Было зарегистрировано в общей сложности 19 видов деревьев, используемых птицами для ночлега. В колючем лесу были отмечены все эти 19 видов, в то время как в сухом лиственном лесу было зарегистрировано только девять видов. Наибольшее количество мест ночлега регистрировалось в Tectona grandis $(\mathrm{n}=27)$, средняя высота деревьев составляла $14.46 \mathrm{м}$, а средняя высота насеста обыкновенного павлина составила 11.25 м. Потеря пищи $(\mathrm{n}=60)$ была причиной снижения вторжения павлина обыкновенного в места проживания человека. Урон урожая от авлина показывает, что бобовые (50\%) сильно повреждались, за ними следуют чили (37\%), томат (5\%), дагусса $(4 \%)$ и кукуруза $(1 \%)$. Водители $(\mathrm{n}=25)$ ответили, что при некоторых обстоятельствах индийский павлин является жертвой убийств на дороге из-за его внезапного появления на дорогах.
\end{abstract}

Ключевые слова: Индия, местообитание, обыкновенный павлин, округ Нилгири, плато Сигур, популяция, штат Тамилнад 